\title{
Operations in Irregular Warfare
}

\author{
Martijn Kitzen
}

\section{Contents}

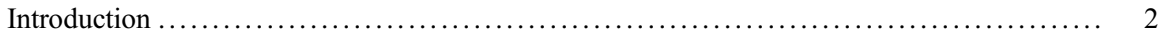

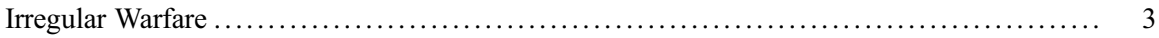

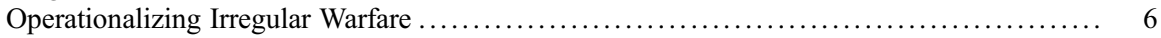

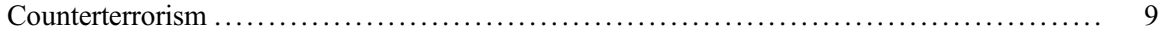

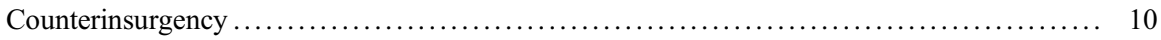

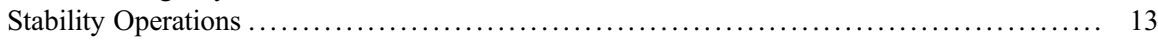

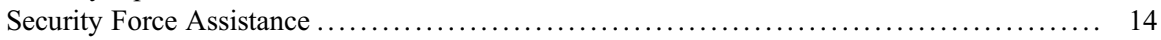

Unconventional Warfare ................................................... 15

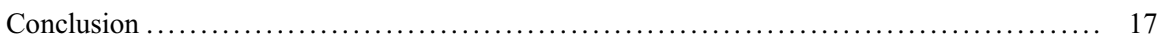

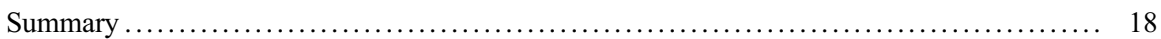

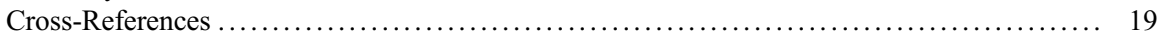

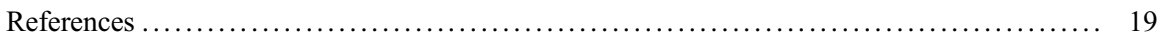

\section{Abstract}

Irregular warfare differs tremendously from the regular, conventional warfare for which Western armed forces traditionally have been optimized. This chapter explores this contrasting form of warfare and its underlying body of knowledge which characterizes irregular conflicts as violent struggles involving nonstate actors and states that seek to establish power, control, and legitimacy over relevant populations. Due to military asymmetry and the political nature of the struggle, the use of force mostly takes unconventional or unorthodox forms and is typically combined with other, non-kinetic, activities. As such, irregular warfare favors an indirect approach that does not focus on military defeat, but on winning the population(s) at stake and eroding the opponent's will. This forces conventionally focused armed forces to adapt to the specifics of an irregular conflict. In order to discuss the way western militaries have operationalized the irregular warfare mission, this analysis first describes terrorism and insurgency, the

M. Kitzen (ه)

Netherlands Defence Academy, Breda, The Netherlands

e-mail: mwm.kitzen@mindef.nl 
dominant forms adopted by irregular opponents. Consequently, the discussion focuses on the five main types of operations: counterterrorism, counterinsurgency, stability operations, security force assistance, and unconventional warfare. To conclude, this chapter not only looks at the way Western armed forces conduct operations in irregular warfare, but also reflects on the topic as a field of knowledge. Ultimately, it is argued that whereas regular and irregular warfare are often considered dichotomous, developments in current warfare have revealed the necessity to consider both forms complementary. Modern militaries, therefore, should structurally embed irregular warfare capabilities in addition to their regular capabilities.

\section{Keywords}

Irregular warfare $\cdot($ Counter)terrorism $\cdot($ Counter)insurgency $\cdot$ Stability operations $\cdot$ Security force assistance $\cdot$ Unconventional warfare

\section{Acronyms}

$\begin{array}{ll}\text { BWT } & \text { By-With-Through } \\ \text { COIN } & \text { Counterinsurgency } \\ \text { CT } & \text { Counterterrorism } \\ \text { F3EA } & \text { Find, Fix, Finish, Exploit, and Analyze } \\ \text { GWOT } & \text { Global War on Terrorism } \\ \text { IED } & \text { Improvised Explosive Device } \\ \text { KLE } & \text { Key Leader Engagement } \\ \text { PRT } & \text { Provincial Reconstruction Team } \\ \text { SFA } & \text { Security Force Assistance } \\ \text { SO } & \text { Stability Operations } \\ \text { UAV } & \text { Unmanned Aerial Vehicle } \\ \text { UW } & \text { Unconventional Warfare }\end{array}$

\section{Introduction}

Western military thought has traditionally been dominated by the idea that wars are fought between militaries of opposing states. This concept of "regular" warfare dictates that armed forces should be optimized for defeating similarly organized opponents on the battle field. Consequently, Western militaries share a deeply rooted preference for conventional operations. Yet, this one-sided focus might be misplaced as history is rife with examples that do not abide to the conventions of regular warfare. Indeed, elusive enemies who seek to avoid battle and employ hit-and-run tactics or even use indiscriminate force against civilians have been there since long before the emergence of conventional armies. Moreover, these armies have a poor track record when it comes to fighting such "irregulars." The experiences in Iraq and Afghanistan, in this regard, are all but exceptional. Yet, the ability to fight irregular opponents has gained in importance recently; the twenty-first-century security 
environment is characterized by an abundance of violent nonstate actors who do not adhere to the principles of regular warfare. This equally applies to the rise of hybrid warfare in which state and nonstate actors alike preferably operate below the threshold of overt war and revert to irregular activities instead. Consequently, the capability to take on missions outside the conventional comfort zone should be a quintessential part of any modern military's tool box. But how does this materialize? This chapter will discuss different types of operations for either dealing with irregular opponents or deploying activities in the irregular realm. For this purpose, the analysis explores various scholarly views toward the subject, and as such it provides an oversight of the underlying body of knowledge. Ultimately, this not only allows for drawing conclusions on the way modern armed forces conduct operations in irregular warfare, but also for reflecting upon these operations as a field of knowledge. First, however, it needs to be clarified what exactly irregular warfare encompasses and how this can be operationalized.

\section{Irregular Warfare}

Obviously, the term irregular is the antithesis of regular. When applied to warfare, therefore, it can be used to describe any conflict that does not involve similarly organized opposing armies that seek to defeat each other on the battlefield in order to secure the interests of their respective states. Yet, such a definition is hardly satisfactory as it merely points out what irregular warfare is not. What, then, is irregular warfare? A starting point for understanding war as a phenomenon is to take a closer look at the purpose for which force is used. Typically, in irregular conflicts armed groups seek to confront states in order to change an existing political order either local, regional, or global. This can be achieved by seizing a territory as for instance the Islamic State's establishment of the Caliphate, or by wresting control of a political system which allows for the redistribution of power and securing the authority over (parts of) a society. Examples of the latter include the violent struggles that are often witnessed in weak or failed states like Afghanistan or Somalia. Thus, the utility of force in irregular warfare is to secure power and control, and therefore this form of warfare is of an inherently political nature.

The most eye-catching feature of irregular warfare is provided by the way in which armed groups seek to obtain their political purpose. This is a logical consequence of the character of the involved actors themselves. Contrary to regular armies the means of nonstate actors and groups fighting as state proxies are relatively limited. The fight between a state's army and an irregular opponent, therefore, is the archetype of military asymmetry (It should be noted, however, that symmetric fights might also occur in irregular conflicts. Think, for instance, of the fighting between various violent extremist factions in the Syrian civil war. Additionally, sophisticated irregular actors might adopt symmetric warfare in order to defeat a regular army in conventional battle - as prescribed by Mao -, or to switch between different forms of warfare. Recent examples of the latter include Hezbollah and Islamic State.). This forces such enemies to carefully manage their scarce resources 
and seek creative ways to effectively deploy them. Schmitt (1963), in this regard, has pointed out that the degree of irregularity of an actor is directly linked to the strength of the regular army it faces. Typically, the resulting unbalance leads to the practice of hiding among relevant populations for survivability and operability. Such a popular sanctuary forms a perfect basis in which fighters can clandestinely hide and wait for an opportunity to attack much stronger conventional forces. Additionally, in most cases involving Western countries, conventional armed forces' ability to escalate will be limited out of fear for civil casualties. Even more important, given the purpose of the struggle, focusing on the population itself offers an excellent opportunity to augment an armed group's power and control, while simultaneously eroding the government's authority, legitimacy, and will. Moreover, augmented influence over the people also allows for the mobilization of new recruits and other resources from within the target society itself. As such, this spin off can be used to mitigate the unbalance in resources. Irregular conflicts, consequently, often take the shape of a competition for control in which violent armed groups and states vie to secure the collaboration of the population(s) at stake (Kalyvas 2006; Kilcullen 2013). The asymmetric character of this type of warfare, thus, favors an indirect approach in which the relevant populations are the essential high ground to be taken. Thereby, irregular warfare is a form of what Smith (2005) has famously dubbed "war amongst the people" in which "civilians are the targets, the objectives to be won, as much as an opposing force" (War among the people is frequently mistaken as being synonym to irregular war. While Smith's argument emphasizes the irrelevance of traditional regular warfare in the contemporary security environment, he adopts a wider scope in which he envisions the dominant influence of various populations in modern war.).

Any act of violence in irregular warfare is intimately related with both its political nature and the centrality of the population. Even seemingly indiscriminate "barbarian" deeds can fit a political purpose as state and nonstate actors alike might use such violence to coerce people into collaboration or deter defection to and cooperation with enemies. Yet, most actors prefer to achieve this purpose through the use of selective force aimed at key individuals. For regular troops, however, the murky character of the struggle makes it hard to distinguish irregulars from civilians. This is what Kalyvas (2006) has labeled "the identification problem." Government forces, therefore, experience difficulties in targeting (those associated with) their enemy, and risk committing random atrocities (As opposed to the deliberate use of indiscriminate violence which serves the purpose of coercing a selected societal group into compliance. This method has been used extensively by, among others, the Syrian regime in the recent civil war. While some scholars point at the effectiveness of this approach, the resulting condition of control is such that it can only be maintained through continuous repression.). In many cases feelings of fear, frustration, or retaliation have lured soldiers into this trap. This directly affects the legitimacy of a state as people will feel alienated and are driven in the hands of the opponent. Moreover, especially Western intervening states will also suffer from a decline in legitimacy of the intervention itself - both at home and internationally. Legitimacy, 
consequently, is a key issue in irregular warfare as it offers a powerful mechanism for justifying both an actor's authority and the use of force.

Generally, both sides in irregular warfare also heavily rely on nonviolent (or nonkinetic) methods that seek to exploit social and psychological mechanisms in order to persuade people to collaborate or to stop supporting the opponent. The global reach of modern communication technology and cyberspace enables both state and nonstate actors to spread powerful narratives aimed at influencing relevant social networks all over the world. Within the conflict itself non-kinetic activities are typically employed for building or enhancing legitimacy. Strengthening the connection with the target population through provision of material support or immaterial goods such as political participation is a well-known catalyst for consolidating control and authority. Yet, it should be explicitly mentioned here that contrary to popular belief "hearts and minds" activities alone do not suffice for winning. Irregular wars are in the first place highly dynamic contests between adversaries who continuously seek to thwart each other's attempts to gain the overhand. This, of course, inevitably involves the use of force.

Due to the asymmetric character of most irregular conflicts the actual fighting between opponents might be limited, yet protracted. Irregular actors are well-known for adopting guerrilla tactics in which they not only hide among the local population, but also make good use of their knowledge of the local terrain. The unconventional, creative use of limited resources allows for the effective application of lethal force against regular opponents. Advances in technology might accelerate this as demonstrated by the huge leaps in insurgent Improvised Explosive Device (IED) capabilities in Iraq and Afghanistan. Thus, armed groups are capable of drawing stronger conventional forces in a protracted battle of attrition. Additionally, such actors might deliberately employ force to provoke a disproportional reaction or to actively undermine the will of an intervening state. Think for instance of the 2004 Madrid bombings that triggered the withdrawal of Spanish forces from Iraq. This demonstrates that, ultimately, it is not the act of force itself, but its political consequences that matter. The very same rationale underlies the reason for adopting a prolonged struggle. While seemingly contradistinctive due to the relatively scarce resources of armed groups, protracted attritional fights hold great potential. Especially when an irregular opponent poses a nonexistential threat, mounting casualties and costs typically start to outweigh a state's interest first and thereby affect its will to continue fighting - especially in case of an intervening power. Moreover, local people will choose the side of the irregulars as they come to realize that a specific group will most probably outstay the foreign forces. Kissinger (1969) accurately described this dynamic of "physical attrition" and "psychological exhaustion," duly pointing out that this boils down to the fact that "the guerrilla wins if he not loses" while "the conventional army loses if it does not win."

To conclude, irregular warfare can be defined as a violent struggle involving nonstate actors (including violent armed groups acting as state proxies) and states with the purpose of establishing power, control, and legitimacy over relevant populations. Due to military asymmetry and the political nature of the struggle, the use of force mostly takes unconventional or unorthodox forms and is typically 
combined with other, non-kinetic, activities. As such, irregular warfare favors an indirect approach that does not focus on military defeat, but on winning the population(s) at stake and eroding the opponent's will (Amidst the myriad of definitions dealing with irregular warfare, this definition borrows most heavily from Kiras' (2016) outstanding work and the US Irregular Warfare Joint Operating Concept 2.0 (2010) which both result from extensive study of theory as well as historical and contemporary practice.). The question that matters here is how modern, conventionally focused, Western-style armed forces can effectively adapt to this form of warfare and which kinds of operations should be adopted for that purpose.

\section{Operationalizing Irregular Warfare}

There is little doubt that fighting irregular opponents provides a challenge of Herculean proportions. While success is hard to achieve, historical experiences have demonstrated that it is not impossible for Western conventional forces to win irregular wars. Yet, this requires adaptation to the form of conflict, the specific enemy, and the local circumstances. While the latter two differ for each unique case, different types of irregular warfare can be distinguished at the macro-level. Kiras (2016), in this regard, has noted that historically terrorism and insurgency are of particular interest for grasping the complexities of modern irregular warfare (Kiras identifies five main categories of irregular warfare: coup d'etat, terrorism, revolution, insurgency, and civil war. In addition to historical reasons, he also points at the fact that terrorism and insurgency due to time and geographic scope are most relevant for studying modern irregular warfare.). Understanding how conventional militaries can adapt to the challenges of such conflicts, therefore, first requires an exploration of these two types.

While there is no consensus on a definition of terrorism, most scholars and practitioners agree it includes the threat or actual use of force in order to attain a political goal through fear, coercion, or intimidation. A terrorist act, thus, serves the purpose of attaining a higher political goal - which can also have a religious, economic, or social character - beyond the immediate victims of the deed itself (LaFree 2018). In order to reach such a larger audience, terrorists aim at symbolic or civilian targets which they typically attack by use of illegal force and violence. Although states might revert to terrorism, the focus here lies at nonstate actors like $\mathrm{Al}$ Qaeda and Islamic State whose actions have had such great consequences for the deployment of Western conventional forces ever since the start of the Global War on Terrorism (GWOT) in 2001. For such groups, terrorism offers a chance to exert influence in the international arena with relatively few resources. Their networks of small cells allow for mounting protracted terrorist campaigns with global reach. This not only applies to terrorist acts themselves, but even more to the capability to influence wider audiences; especially cyberspace has proven itself a powerful accelerator for conveying the so-called propaganda of the deed. Thus, modern nonstate actors can seek to convince a target population and its political leadership to comply to its demands as the perceived costs of vicious attacks outweigh the 
interests at stake. Next to this coercive mechanism, terrorism can also function as a reactive strategy that seeks to provoke an opponent to (over)react in such a way that its interests are damaged. Probably the best example is given by the $9 / 11$ attacks that have lured the USA in actions that not only have been costly in terms of lives and resources, but also played into the hands of Al Qaeda (Kilcullen 2009). Moreover, the GWOT is still ongoing and its results have been questionable at best. Al Qaeda, although seriously reduced, has not been eliminated and has shown remarkable resilience. Furthermore, the emergence of new groups such as Islamic State can at least be partly attributed to conditions created by the very interventions that sought to end terrorism. All in all, it is obvious that terrorism confronts modern militaries with serious challenges.

In the discourse on military operations terrorism and insurgency have often been used interchangeably (Kitzen 2012). Yet, there is a profound difference between both forms of irregular warfare. Insurgency in essence is a hybrid form of warfare that combines subversion, guerrilla, and terrorism in order to establish political control over (parts of) a country or region. To add to the complexity, insurgents indeed might use terrorism as a tactic to coerce people to comply to the group's demands. The difference with terrorist groups lies in the fact that such deeds are used in support of other methods for establishing control. That is exactly the reason why the use of terrorism against civilian targets by insurgents is a rather precarious issue as too much indiscriminate violence might turn people against the insurgency and thus negatively affect the quest for control. Subversion, in this respect, is paramount for achieving the political goal and insurgencies typically first strive to expand their support base. Convincing local people that they are better off by supporting the insurgency is truly an art which might be applied so effective that a country can be out-administered by an insurgent shadow administration (Fall 1965). Moreover, popular support also allows insurgents to hide among the people and recruit new fighters. Both are pivotal for mounting a protracted campaign, and this is exactly why Mao has famously called the population the native element, "the water," on which the insurgents, like "fish," depend to survive and fight (Mao 2000). Parallel to these activities, insurgents employ guerrilla tactics in order to compensate for their military asymmetry. This use of force is also subordinated to the overall goal of establishing political power and functions to enhance the group's position vis-à-vis the state. The military activities serve to either strengthen the insurgency itself by seizing territory and resources or to undermine the opponent. As aforementioned, the latter might materialize in a protracted campaign of attrition that intends to erode a government's will. In sum, the combination of subversion, guerrilla, and terrorism renders insurgencies formidable opponents who are not only highly capable of establishing control over a target population, but due to their elusive and persistent character are also extremely difficult to fight. The wars in Iraq and Afghanistan have illustrated this repeatedly. Despite many tactical successes, the intervening forces and their local allies did not defeat the irregular opponents. Both the various Iraqi insurgencies and the Taliban in Afghanistan never lost their ability to exert (and expand) influence over significant parts of the local population. 
How can Western-style militaries tackle the challenges of irregular warfare? It is clear that the operational problems encountered differ tremendously from the conventional battles most armed forces are optimized for. Practicing irregular warfare requires the ability to operate among the population and deploy a mix of kinetic and non-kinetic activities as demanded by the operational puzzle at hand. Successful adaptation, therefore, not only requires a change of mindset, but also integration of nonmilitary means in the military organization. Western armed forces, in this regard, have developed five types of operations that allow them to operationalize their irregular warfare capabilities. Obviously, the first two kinds of operations are counterterrorism (CT) and counterinsurgency (COIN) as these forms of irregular warfare pose the most widespread threat. The following two types, stability operations (SO) and security force assistance (SFA), are intimately related as they seek to mitigate such threats by bolstering, respectively, a fragile host nation's overall ability, or more specific the capabilities of local security forces. These four kinds of operations, thus, are all intended to counter irregular threats, and therefore they can be characterized as defensive strategies - which do not exclude a more offensive character at the operational or tactical level. But what about the offensive use of irregular warfare? This is addressed by the last type of operation, unconventional warfare (UW), which is all about "being irregular" as it encompasses the deployment of (support to) irregular activities to undermine an opponent in an indirect way.

By discerning these five main types of irregular warfare operations, this analysis more or less concurs with US Irregular Warfare Joint Operating Concept 2.0 (The main difference with the Joint Operating Concept lies in the fact that it does not include security force assistance, but instead contains so-called foreign internal defense. The latter kind of operations is unique to the USA and concerns the deployment of military and other means in support of a host nation's efforts for protecting its society against irregular threats. For the military this typically boils down to security force assistance operations, which as such is embraced as a key activity by, among others, NATO. It should also be noted here that work on a new US Irregular Warfare Joint Operating Concept is in progress.) (Department of Defense 2010). This concept also highlights the overlap between the different types and explains that a coherent campaign against an irregular threat might include any mix of these operations undertaken in either sequence, parallel, or in blended form. Both the wars in Afghanistan and Iraq, for instance, have included all different types of operations. Especially in Afghanistan - and to a lesser extent in Northern Iraq - the emphasis first lay on unconventional warfare, while the main part of both campaigns encompassed a mix of counterterrorism, counterinsurgency, and stability operations, for which security force assistance was also necessary. Since massive commitment of forces ended, the focus in both wars has shifted to this latter type supported by counterterrorism when necessary. Whereas the main forms of irregular warfare operations, thus, can be deployed in any combination or on their one, they all share a dependence on several other key activities. Among these activities, intelligence gathering is probably most salient as its nature differs considerably from regular warfare. Solving the identification problem, after all, requires a thorough understanding of the human terrain which demands different knowledge and skills 
than analyzing the whereabouts and intentions of conventional enemy formations. Similarly, the population-centric nature of irregular war also requires armed forces to engage in activities such as strategic communication, information operations, and psychological operations. These, however, are always conducted in support of the five types of irregular warfare operations, and hence this analysis will focus on these main forms.

\section{Counterterrorism}

The special forces raids that eliminated Al Qaeda leader Osama bin Laden (2011) and the Islamic State's self-proclaimed caliph Abu Bakr al Baghdadi (2019) are often portrayed as the epitome of the fight against terrorism. Yet, such operations form only the tip of the iceberg as counterterrorism typically demands a much wider, whole-of-government approach that, among others, also addresses the causes of violent extremism and the financial backing of terrorist organization. Even the military role itself is much broader than killing or capturing terrorists. In addition to being an integral part of a state's international (counterterrorism) policy, armed forces are also deployed in support of domestic civil authorities. Here, however, the focus lies on the former, as this has become a staple of military studies.

Whereas counterterrorism at the strategic level is a defensive, reactive strategy, operations abroad in general hold an offensive character; they mostly serve the purpose of retaliating against the perpetrators of an attack or preempting (new) terrorist deeds. In case of state(-sponsored) terrorism retaliatory attacks seem an obvious choice to coerce the target state to give up its backing of terrorist groups. Such operations mostly have a conventional character as illustrated by the 1986 US air raid against the Gaddafi regime following the bombing of a nightclub by Libyan agents. Even when the terrorist threat comes from an elusive nonstate actor retaliation might be exerted. An example is provided by the launch of cruise missiles against Al Qaeda targets in Sudan and Afghanistan in the wake of the 1998 East Africa embassy bombings. Yet, overall the effectiveness of retaliation is doubtful as this might also provoke new terrorist attacks or escalate in full war. In both mentioned examples the terrorists reacted with even more vicious attacks, respectively, the bombing of a Pan Am airliner that came down at Lockerbie and, most infamously, the 9/11 attacks on the Pentagon and the Twin Towers. It should also be reminded that the Afghan War originally started as a punitive campaign against the perpetrators of those latter attacks. Under the banner of the GWOT this counterterrorism operation soon resulted into a protracted irregular war.

As the GWOT expanded, its rationale shifted from retaliation into preemption; fighting terrorists "over there" was considered far better than awaiting terrorist attacks at home (Boyle 2018). This led to the conduct of counterinsurgency, stability, and security force assistance operations as part of the overarching counterterrorism strategy. Counterterrorism operations, however, have remained at the forefront and also have assumed a preemptive character that serves to deter or disrupt terrorist organizations (Finegan 2018). While mopping up hideouts and eliminating terrorist 
leaders might be considered traditional military tasks, such preemptive operations have quickly evolved during the GWOT. Special forces took the lead in optimizing the targeting process which has resulted in operations designed and executed conform the "find, fix, finish, exploit, and analyze" (F3EA) concept (McChrystal 2011). This encompasses finding the target by the combined efforts of analysts, fixing the target with observation means such as unmanned aerial vehicles (UAVs), the actual execution of the operation ("finish") by combat teams, exploitation of the intelligence gathered during the operation, and analyzing this into new actionable information. This methodology has allowed Western armed forces to capture and kill violent extremists in an unprecedented, relentless pace. Additionally, UAVs have become ever more important in the execution of targeted killings. This combination of the so-called "drones" and special forces provides politicians with a relatively cheap and low-risk option for taking the fight to terrorists and preempt any new terrorist attacks. Among others, this development has led to the emulation of special forces actions by conventional units. Far more important, however, is the tendency of senior political and military leadership to rely on this relative cheap option exclusively. As mentioned at the very beginning of this section, counterterrorism requires a wider approach and too much emphasis on targeting might turn out counterproductive, especially since its long-term effects are uncertain.

\section{Counterinsurgency}

Whereas military operations in counterterrorism have evolved into highly specialized kinetic activities, counterinsurgency operations are of a more comprehensive nature. Western militaries have adopted the ideas of the so-called population-centric school of counterinsurgency which aims at defeating an insurgency by winning the struggle for the population. The general idea of this indirect approach is to strengthen the legitimate authority of a government and thereby enhance its control over the involved society, while simultaneously weakening the insurgent's ability to exert influence over the populace. This contrasts the enemy-centric school that involves the use of brutal force to wipe out insurgents and their supporters and which is typically practiced by authoritarian regimes. Due to the identification problem, indiscriminate force is almost inherent to this form of counterinsurgency, and mass casualties are no exception. The actions of the Assad regime during the Syrian civil war are a case in point. This explains why Western militaries have taken the population-centric turn in counterinsurgency. How has this materialized in operational art?

To start, counterinsurgency demands adaptation to both the specifics of the operational environment as well as the tasks at hand. Kinetic activities are conducted amidst the people and therefore force should be applied carefully. Equally important, troops also have to conduct nonmilitary, non-kinetic tasks which often differ tremendously from the jobs they originally trained for. In this regard, counterinsurgency roughly reflects Krulak's concept of three block war as soldiers should be capable of shifting between various complicated tasks ranging from delivering aid, 
reconciling feuding factions, and fighting the insurgents (Krulak originally used this concept for describing the military's role in the complex peace keeping situations of the 1990s.) (Krulak 1999). Indeed, counterinsurgency encompasses three core activities, sometimes labeled the 3 Ds as they respectively cover the fields of Defense, Diplomacy, and Development. This distinction clearly hints at the wholeof-government nature of counterinsurgency campaigns. These undertakings, therefore, are interagency efforts that involve different governmental agencies, as well as contributions from international and nongovernmental organizations. The truth is, however, that such a comprehensive or integrated approach is difficult to realize in modern warfare in which coalitions of various countries fulfill an important role. Even a relatively well-oiled bureaucracy like NATO found it very difficult to implement this in Afghanistan. Moreover, as especially civil agencies suffer from a lack of capacity for foreign deployments, soldiers bear most of the burden. This not only manifests itself in the fact that troops fulfill military as well as nonmilitary tasks, but also in the fact that such endeavors typically are designed and led by the military whereas joint civil-military leadership would be ideal.

In order to put this complicated comprehensive approach into practice the most influential counterinsurgency doctrine, US Army Field Manual 3-24, prescribes that a task force's operational framework should consist of various lines of operations that are intended to orient the force toward and reach goals in all three core realms (The original 2006 version of the FM 3-24 talks about lines of operations, while the 2014 revised version renames them lines of effort. The former version functioned, among others, as the guideline for the turnaround in US operations in Iraq during the 2007 Surge and NATO operations in Afghanistan around 2010-2011. As a consequence of its importance in modern warfare this analysis has opted to maintain the terms from the 2006 version. The 2014 revision, however, is based on an even better analysis of the operational challenges and is a worthy successor of the original publication.) (Department of the Army 2006, 2014). Examples include combat operations and security force assistance - which thus can be included as a subtype of operations in counterinsurgency - to step up security, socioeconomic aid and provision of essential services in order to boost development, and promotion of good governance to enhance the legitimate authority of the (host-nation) government. It has to be mentioned that this closely matches stability operations which, therefore, can be part of counterinsurgency. This will be further dealt with below.

Since in counterinsurgency it is all about winning the competition for the population, it is important to realize that every action potentially exerts influence. Hence it is important that soldiers develop sufficient situational awareness and that all activities are closely synchronized. This latter aspect is covered by so-called information or influence activities, a separate line of operations that seeks to maximize the counterinsurgents' influence on the local population and that also aims to influence the perceptions of people in the wider region and at home. Ultimately, however, all of this depends on situational awareness as a proper understanding of the social landscape is a prerequisite for both the design and the conduct of operations among the people. 
The wars in Iraq and Afghanistan have spawned some harsh lessons on the actual conduct of counterinsurgency operations in the everyday reality of modern warfare. On the tactical level a bifurcation of tasks could be observed; special forces adopted their counterterrorism targeting practices for deterring and disrupting insurgencies, combat forces focused on securing the population, and specialized Provincial Reconstruction Teams (PRTs), which also involved civilian experts, delivered development aid, and strengthened the local government. Optimal operations required the integrated deployment of these tools, and despite their specialization, all types of units could be confronted with the need to shift between various tasks as demanded by the local situation. Another key insight concerns the rationale beyond the strengthening of government. Whereas the initial focus in both Iraq and Afghanistan lay on establishing a working democracy, this gradually altered into a more hybrid form of government including local power-holders who enjoyed legitimacy on other grounds than being elected. Such leaders, for instance, were instrumental in the 2006-2007 Anbar awakening which gave a huge impetus to the campaign in Iraq. As mentioned afore an appropriate understanding of the local society is pivotal, and as campaign plans were adjusted to this new insight, soldiers also benefited by integrating the so-called key leader engagement (KLE) in their daily routine. The pattern of legitimate authority in the target society, therefore, should be incorporated in both the design of campaigns and the actual conduct of operations (Kitzen 2017).

The ultimate lesson of both wars concerns the failure of counterinsurgency. While significant adaptation led to operational successes, the overall campaigns stalled due to a lack of will from the side of the intervening states. It simply took too long to adopt the right strategy. A RAND study has revealed that the average time needed for achieving success after implementing effective practices is 69 months (Paul et al. 2013). That amount of time, however, seems too much considering the lack of political patience that could be observed in both cases (In Iraq effective practices were adopted during the 2007 surge, while in Afghanistan the revision of the campaign which was completed in 2011 had a similar effect. End of the counterinsurgency missions took place in 2011 and 2014, respectively.). Combined with the relatively limited resources, this time pressure has acted as a catalyst for the emergence of so-called counterinsurgency lite or accelerated counterinsurgency (Kilcullen 2012). This new form of counterinsurgency envisions the simultaneous and mutually amplifying deployment of targeting, security operations, and reconciliation efforts in order to achieve an acceptable level of control and stability within a limited amount of time. That result, consequently, serves as the underpinning for a long-term effort by the host-nation itself with support from the international community (through stability operations, security force assistance, and nonmilitary aid). As such the contours of future counterinsurgency have revealed themselves in the latter days of the campaigns in Iraq and Afghanistan. 


\section{Stability Operations}

Stability operations are intimately related to their counterinsurgency brethren. Actually, as mentioned afore, they might even be integrated in counterinsurgency efforts since they share many aspects; both encompass enhancing the population's security, delivering development aid, and advancing good governance. What, then, are the differences? First, the main purpose of stability operations is not to fight insurgencies, but to establish a stable environment in weak or failed states. The rationale underlying this concept is that irregular threats for international security might benefit from weakly or ungoverned spaces - so-called black holes - and, therefore, intervention is to act as a tool to forestall this. Strategically, stability operations, thus, are of a preventive nature. This echoes in their purpose which concerns effecting a transformation from a situation of potential violent conflict toward a viable longterm solution (Tuck 2014). Counterinsurgency, by contrast, aims at establishing an acceptable level of stability. While stability operations in the past have been criticized as social-engineering efforts pursuing the utopian long-term goal of building Western-type states in fragile countries, recent experiences have led to more realistic approaches that foster sustainable local solutions. The rule that "social context is king (Kitzen 2016)," therefore, also applies to stability operations.

A second difference concerns sequencing. Due to their nature these operations have traditionally been executed after the end of either an irregular or regular conflict in order to consolidate and expand the achieved level of stability and prevent the reemergence of violence. In irregular warfare, however, this process typically is far more complicated as weak or failed states lack an administrative infrastructure. Furthermore, stability operations are also closely related to peacekeeping and peacebuilding since they are mostly conducted in the post-conflict stabilization phase (Brocades Zaalberg 2012). Yet, when part of a counterinsurgency campaign, these efforts might take place while fighting is still ongoing. This can be explained by the character of counterinsurgency, which demands an approach tailored to the specifics of each locale. Even when the overarching conflict has not been settled yet, the situation at the grass roots level can differ tremendously. A counterinsurgency force, therefore, might need to focus on fighting the insurgents in one place, while conducting stability operations in another. Lastly, this type of operations is also heavily relied on to prevent the outbreak of a potential irregular conflict. So-called phase zero or contingency operations concern the deployment of forces to a country in (an emerging) crisis caused by either an internal threat or spill-over from regional conflicts. While often executed by special forces, this might also be executed by regular units as, for instance, can be observed in various missions assisting countries in the Sahel.

Ideally stability activities require close civil-military cooperation at all levels. However, just like in counterinsurgency, reality mostly boils down to the fact that soldiers perform the bulk of tasks. This is inherently related to the lack of long-term commitment, which hampers the adoption of long-term strategies for integrated deployment of different capabilities. Consequently, recent stability efforts have a 
tendency to focus on security force assistance in order to allow a host-nation to maintain a secure and stable environment by itself. The follow-up of the counterinsurgency efforts in Iraq and Afghanistan provides a case in point as troop levels were quickly reduced and swapped for "Iraqization" and "Afghanization," respectively. Whereas there is little doubt about the importance of training host-nation security forces, accompanying economic development support and aid for governance reforms lagged behind. Recent stability operations, therefore, have spawned the insight that the reemergence of grand strategy is pivotal for "shaping the way wars end and their aftermath" (Cordesman 2017).

\section{Security Force Assistance}

Security force assistance has already been mentioned repeatedly since this activity might be employed in support of all aforementioned types of operations. Moreover, it might also be part of regular warfare as this activity seeks to bolster a country's ability to counter both internal and external threats. The focus here, however, lies on irregular warfare where security force assistance is conducted in support of a legitimate authority's effort to fight irregular opponents like violent extremist organizations. The aim is to develop a sustainable capability that allows a government to durably maintain a safe and secure environment for its population. These operations encompass the deployment of relatively small groups of military personnel in order to help in (re-)building and (re-)organizing the host-nation security sector in its broadest sense. Typically, troops might be involved in educating, training, and reequipping armed and police forces, border guards, etc. Another key activity concerns actual assistance during operations. This takes the form of soldiers performing advising, liaison, and mentoring duties in the field. Additionally, specialized units or assets might be dispatched as enablers for host-nation partner units. Examples include the deployment of air support, explosive ordnance disposal, medical, and intelligence capabilities. Thus, albeit that security force assistance operations require a relatively light foot print, they comprehend a whole range of different activities as well as a mix of units and assets tailored to the requirements of a specific host-nation.

The irregular warfare security force assistance mission has traditionally been the turf of special forces. Under the moniker "military assistance" operators set out to bolster partner units and when necessary other assets and troops were deployed in support of this effort. Recently, however, the trend has emerged that this mission is increasingly executed by regular units (Wiltenburg 2019). This partially is the consequence of Western reluctance to deploy large number of ground forces after the costly experiences in Iraq and Afghanistan. Instead interventions now preferably take the form of so-called "remote warfare" in which opponents like the Islamic State, Al Qaeda, Al Shabaab, Boko Haram, and the Taliban are fought by local partners predominantly (Knowles and Watson 2018). The US' adoption of the socalled "by-with-through" (BWT) operational approach offers perhaps the strongest 
illustration of this point. BWT, which has been a mainstay of, among others, the fight against the Islamic State, heavily relies on indigenous forces. It envisions that ideally operations are led by local partners (including local legitimate nonstate actors like the Syrian Kurds), with enabling support from US and coalition forces, and made possible through US authorities and partner agreements (Votel and Keravuori 2018). These developments have raised the demand for security force assistance and therefore these operations, while still part of the special forces mission set, have progressively entered the realm of regular units. Various armed forces in this regard have established specialized (and sometimes regionally aligned) units that focus on capacity building and forging partnerships with local allies. Thus, security force assistance is becoming more and more embedded in the thinking and organization of armed forces.

While these developments suggest that this type of operation provides a perfect solution to project combat power at minimal costs, there are also serious risks involved. Misalignment in interest between local authorities and governments deploying security force assistance forms a common risk that can seriously limit the utility of such operations (Biddle et al. 2018). This clearly demonstrates the endemic weakness of assisting troops under control of another party. Especially, when policy deviations between assisting and assisted widen, this might render missions ineffective or even counterproductive. In Iraq, for instance, the Shiadominated government's sectarian course increasingly thwarted US efforts to rebuild the Iraqi security sector. This not only left the Iraqi armed forces ill-prepared for their tasks, but also played into the hands of Iran. Ubiquitous security force assistance operations, therefore, are no silver bullet, but should be practiced and monitored carefully and with a clear understanding of local interests and power dynamics.

\section{Unconventional Warfare}

The last type of operation is the only one that requires soldiers to act as irregulars themselves. Unsurprisingly, such unconventional warfare operations have been the domain of special forces with other components acting as enablers when necessary. This, however, is not only a result of their specific irregular, clandestine nature, but also because of the strategic effects that can be attained through these operations. Unconventional warfare is truly an instrument of statecraft as it allows a government to leverage (parts of) other populations to act in a way that serves its interest best. As such it might be deployed in support of regular warfare, against states who themselves wage war by use of nonstate proxies, or against occupying powers and nonstate actors that have successfully established control over a considerable population and territory. The purpose of these operations is either to coerce a hostile power to act in another way, to disrupt it by destabilizing its authority so it can no longer effectively take adverse actions, or to overthrow a (shadow) government or enforce the withdrawal of an occupying force. How exactly is this accomplished? 
A typical unconventional warfare operation sees special forces teaming up with local resistance groups, insurgencies, or opposition groups (Brown 2017). Support to these irregular allies can range from supplying, training, and advising to actual combat assistance. All these activities take place to allow for the expansion of the support base and stepping up the momentum of antigovernment operations. The opposing government, thus, will suffer from both an erosion of popular support and attrition of its security forces. While such an unconventional warfare campaign might be a protracted effort that ultimately seeks to overthrow a hostile regime, it can be accelerated through the introduction of conventional forces. It should be clear, however, that the support of local irregular groups first and foremost serves the overarching strategic purpose. Depending on this purpose the alignment with such actors should be explored carefully prior to designing an unconventional warfare campaign. While differences in interests to a certain extent are unavoidable, most important is to vet whether there is sufficient common ground and shared interest to obtain the desired effects. This not only requires thorough knowledge of local irregular groups and their objectives, but also insight in their relations with the population as well as the potential they possess for successfully influencing people. Understanding the human domain, therefore, is essential for achieving success in unconventional warfare.

As a consequence of the emphasis on local irregular partners the costs and risks are relatively low. This explains why such operations are highly attractive in modern warfare. Just like security force assistance, this type seems increasingly important and seemingly fits new concepts like BWT as illustrated by the role of Syrian Kurdish forces in the fight against the Islamic State. Yet, this case also shows the importance of proper alignment as the sudden withdrawal from US forces in 2019 painstakingly revealed. Whereas the Islamic State's shadow government has been successfully defeated, the long-term consequences of abandoning the Kurdish allies might provide a serious backlash. This is especially significant as it creates doubt about whether irregular groups can trust the US and other Western countries as allies. In the current era of renewed big power competition in which hybrid warfare has enlarged the weight of operations below the threshold of overt conflict, unconventional warfare has become ever more important (Kilcullen, in this regard, has introduced the concept of "liminal (Latin for threshold) warfare" in which irregular actors seek to exploit the gap between detection, attribution, and response thresholds.) (Kilcullen 2019; Votel et al. 2016). Acting as a good ally, therefore, is more crucial than ever. Furthermore, in the near future unconventional warfare is expected to evolve considerably for enhancing the ability to influence populations and deal with threats in the so-called gray zone between peace and conflict. Due to the nonlinear character of current trends, however, it is unpredictable which direction this will take. Therefore, unconventional warfare operations should be assessed and adapted continuously to keep up with these developments. 


\section{Conclusion}

This chapter has repeatedly hammered at the fact that irregular warfare operations differ tremendously from the conventional, regular warfare activities for which Western armed forces traditionally have been optimized. Instead of defeating the opponent's armed forces on the battle field, irregular conflicts favor an indirect approach that concentrates at winning the struggle for the relevant population(s) and eroding the opponent's will. This violent struggle involves state and nonstate groups (including state proxies) which seek to establish power, control, and legitimacy over the people at stake. Combined with military asymmetry, the political nature of such conflicts materializes as a mix of unconventional or unorthodox kinetic and non-kinetic activities. Consequently, Western forces need to adapt to this form of warfare, the specific enemy, as well as the human terrain in which the struggle takes place.

In order to counter irregular threats militaries have adopted four types of operations of a strategically defensive nature. These are respectively counterterrorism, counterinsurgency, stability operations, and security force assistance. Obviously, the former two are responses to the most prevalent irregular threats of terrorism and insurgency, while the latter two are also closely related to the fight against these opponents. A fifth type of operation, unconventional warfare, is of a strategically offensive nature and encompasses the ability of armed forces to operate as irregulars themselves. This analysis has revealed that while success is hard to achieve and operational (as well as strategical) challenges might be tremendous, these five operations (either in combination or individually) allow regular militaries to effectively adapt to modern irregular warfare.

The here presented insights are the result of hard gained experiences that form the empiric evidence for the underlying field of knowledge. At the fundamental level this field seeks to understand the dynamics that define the nature of irregular conflicts as well as to answer strategic questions about, among others, the utility of force, the human terrain, and the character of asymmetric opponents. The need to operationalize irregular warfare has triggered studies on military adaptation as well as that it has led to the emergence of studies in terrorism and insurgency that seek to enhance the understanding of these predominant forms of irregular conflict. With regard to the different types of operations, counterterrorism and counterinsurgency have drawn the most scholarly attention. The effectiveness of respectively targeting and population-centric counterinsurgency remains topic of debate and thereby is firmly established on the research agenda. Related to this is the matter of remote warfare in which stability operations and security force assistance have also gained in importance to address the issue of how irregular wars might be fought far from home with relatively few resources. Last, unconventional warfare's link with hybrid warfare's imperative to operate below the threshold of overt war has triggered a growing academic interest. 
The current state of operations in irregular warfare as both a field of practice and knowledge seemingly indicates that lessons are being learned. Yet, Western armed forces have a notorious bad track record of learning from irregular wars. Historically, a trend can be discerned in which a period of irregular experiences is followed by a return to the "normalcy" of regular warfare. This is not only a consequence of military culture, but also of the typical lack of political success in irregular warfare. Western armed forces, therefore, seem doomed to reinvent the wheel every time they need to adapt for waging irregular war (Kitzen 2019). After the experiences in Iraq and Afghanistan most militaries have again moved toward the downside of this cycle as lessons have not been properly institutionalized. While to a smaller extent some insights have been incorporated, the general trend is that militaries are again preparing for large-scale interstate combat. The reemergence of big power competition, in this respect, has acted as a catalyst triggering this reorientation. The hybrid character of modern warfare, however, requires the ability to conduct both regular and irregular warfare operations. Therefore, the cycle of unlearning irregular experiences should be broken and appropriate capabilities firmly embedded in the military organization and strategic thinking as soon as possible. This requires soldiers to think beyond the dichotomy of regular and irregular warfare and instead accept the idea of both forms as complementary and making up a continuum to be deployed against hybrid threats. Only by embracing irregular warfare operations and the underlying body of knowledge in addition to traditional tasks and ideas today's militaries will prepare themselves for fighting tomorrow's wars.

\section{Summary}

This chapter has explored irregular warfare as a contrasting form of warfare that differs tremendously from the regular, conventional warfare for which Western armed forces traditionally have been optimized. The underlying body of knowledge conceptualizes irregular conflicts as violent struggles involving non-state actors and states that seek to establish power, control, and legitimacy over relevant populations. Due to military asymmetry and the political nature of the struggle, the use of force mostly takes unconventional or unorthodox forms and is typically combined with other, non-kinetic activities. As such, irregular warfare favors an indirect approach that does not focus on military defeat, but on winning the population(s) at stake and eroding the opponent's will. This forces conventionally focused armed forces to adapt to the specifics of an irregular conflict. In order to understand this adaptation process, the chapter has first discussed terrorism and insurgency as dominant forms of irregular warfare. Consequently, the five main types of operations that allow regular armies to adopt to irregular war have been described: counterterrorism, counterinsurgency, stability operations, security force assistance, and unconventional warfare. To conclude, the chapter has not only provided an insight in the way Western armed forces conduct operations in irregular warfare, but also reflected on the topic as a field of knowledge. From that point of view it has been argued that the topic is of enduring importance and that whereas regular and irregular warfare are 
often considered dichotomous, developments in current warfare have revealed the necessity to consider both forms complementary. Modern militaries, therefore, should structurally embed irregular warfare capabilities in addition to their regular capabilities.

\title{
Cross-References
}

\author{
Counterinsurgency Operations \\ Intelligence Operations \\ Military Design \\ - National Strategy \\ - Peace Support/Building/Enforcement Operations \\ $\checkmark$ Regional Studies \\ - Strategic Communication \\ - Strategic Culture in the Military \\ - Strategy and Doctrine \\ - What is Military Operations?
}

\section{References}

Biddle, S., Macdonald, J., \& Baker, R. (2018). Small footprint, small pay off: The military effectiveness of security force assistance. Journal of Strategic Studies, 41, 1-2.

Boyle, M. J. (2018). The military approach to counterterrorism. In A. Silke (Ed.), Routledge handbook of terrorism and counterterrorism. London: Routledge.

Brocades Zaalberg, T. W. (2012). Counterinsurgency and peace operations. In P. B. Rich \& I. Duyvesteyn (Eds.), The Routledge handbook of insurgency and counterinsurgency. London: Routledge.

Brown, T. D. (2017). Unconventional warfare as a strategic force multiplier: Task force Viking in northern Iraq, 2003. Tampa: JSOU Press.

Cordesman, A. (2017). Stability operations in Syria, The need for a revolution in civil-military affairs. Military Review, 2-21. May-June 2017.

Department of the Army. (2006). FM 3-24, counterinsurgency. Washington, DC: Department of the Army.

Department of the Army. (2014). FM 3-24, counterinsurgency. Washington, DC: Department of the Army.

Fall, B. B. (1965). The theory and practice of insurgency and counterinsurgency. Naval War College Review, $18,3$.

Finegan, R. (2018). Targeted killings, perpetual war for perpetual peace? In A. Silke (Ed.), Routledge handbook of terrorism and counterterrorism. London: Routledge.

Kalyvas, S. N. (2006). The logic of violence in civil war. Cambridge: Cambridge University Press.

Kilcullen, D. (2012). Counterinsurgency: The state of a controversial art. In P. B. Rich \& I. Duyvesteyn (Eds.), The Routledge handbook of insurgency and counterinsurgency. London: Routledge.

Kilcullen, D. (2013). Out of the mountains, the coming of age of the urban guerrilla. New York: Oxford University Press.

Kilcullen, D. (2019). The evolution of unconventional warfare. Scandinavian Journal of Military Studies, 2, 1. 
Kilcullen, D. (2009). The accidental guerrilla, fighting small wars in the midst of a big one. New York: Oxford University Press.

Kiras, J. (2016). Irregular warfare. In D. Jordan et al. (Eds.), Understanding modern warfare. Cambridge: Cambridge University Press.

Kissinger, H. (1969). The Vietnam negotiations. Foreign Affairs, 47, 2.

Kitzen, M. (2012). Western military culture and counterinsurgency: An ambiguous reality. Scientia Militaria, South African Journal of Military Studies, 39(2), 1-24.

Kitzen, M. (2016). The Course of Co-option: Co-option of local power-holders as a tool for obtaining control over the population in counterinsurgency campaigns in weblike societies. Amsterdam University, Doctoral Dissertation.

Kitzen, M. (2017). 'Legitimacy is the Main objective': Legitimation in population-centric counterinsurgency. Small Wars \& Insurgencies, 28, 4-5.

Kitzen, M. (2019). Conventional and unconventional war are not opposites. War Room, March 28, $2019 \mathrm{https} / / /$ warroom.armywarcollege.edu/articles/conventional-and-unconventional-war-arenot-opposites/

Knowles, E., \& Watson, A. (2018). Remote warfare, lessons learned from contemporary theatres. London: Oxford Research Group.

Krulak, C. (1999). The strategic corporal: Leadership in the three block war. Marines Magazine, January 1999.

LaFree, G. (2018). Conceptualizing and measuring terrorism. In A. Silke (Ed.), Routledge handbook of terrorism and counterterrorism. London: Routledge.

Mao Tse-tung (2000). On guerrilla warfare (trans. Samuel B. Griffith II). Urbana: University of Illinois Press.

McChrystal, S. (2011). It takes a network. The new frontline of modern warfare. Foreign Policy, 21 Feb 2011.

Paul, C., Clarke, C., Grill, B., \& Dunigan, M. (2013). Paths to victory, lessons from modern insurgencies. Santa Monica: RAND.

Schmitt, C. (1963). The theory of the partisan: A commentary/remark on the concept of the political. Berlin: Duncker \& Humblot.

Smith, R. (2005). The utility of force, the art of war in the modern world. London: Allen Lane.

Tuck, C. (2014). Understanding Land Warfare. London: Routledge.

US Department of Defense. (2010). Irregular warfare: Countering irregular threats, joint operating concept version 2.0. Washington, DC: Department of Defense.

Votel, J. L., \& Keravuori, E. R. (2018). The by-with-through approach. Joint Forces Quarterly 89, 40-47.

Votel, J. L., Cleveland, C. T., Connett, C. T., \& Irwin, W. (2016). Unconventional warfare in the gray zone. Joint Forces Quarterly 80, 101-109.

Wiltenburg, I. (2019). Security force assistance: Practised but not substantiated. Militaire Spectator, $188,2$.

\section{Further Reading}

Jones, S. G. (2017). Waging insurgent warfare, lessons from the Vietcong to the Islamic state. New York: Oxford University Press.

Kalyvas, S. N. (2006). The logic of violence in civil war. Cambridge: Cambridge University Press.

Kilcullen, D. (2019). The evolution of unconventional warfare. Scandinavian Journal of Military Studies, $2,1$.

Kiras, J. (2016). Irregular warfare. In D. Jordan et al. (Eds.), Understanding modern warfare. Cambridge: Cambridge University Press.

Mackinlay, J. (2009). The insurgent archipelago, from Mao to bin Laden. London: Hurst and Company. 
Rich, P. B., \& Duyvesteyn, I. (Eds.). (2012). Routledge handbook of insurgency and counterinsurgency. London: Routledge.

Paul, C., Clarke, C., Grill, B., \& Dunigan, M. (2013). Paths to victory, lessons from modern insurgencies. Santa Monica: RAND.

Silke, A. (Ed.). (2018). Routledge handbook of terrorism and counterterrorism. London: Routledge.

Smith, R. (2005). The utility of force, the art of war in the modern world. London: Allen Lane.

US Department of Defense. (2010). Irregular warfare: Countering irregular threats, joint operating concept version 2.0. Washington, DC: Department of Defense.

Open Access This chapter is licensed under the terms of the Creative Commons Attribution 4.0 International License (http://creativecommons.org/licenses/by/4.0/), which permits use, sharing, adaptation, distribution and reproduction in any medium or format, as long as you give appropriate credit to the original author(s) and the source, provide a link to the Creative Commons license and indicate if changes were made.

The images or other third party material in this chapter are included in the chapter's Creative Commons license, unless indicated otherwise in a credit line to the material. If material is not included in the chapter's Creative Commons license and your intended use is not permitted by statutory regulation or exceeds the permitted use, you will need to obtain permission directly from the copyright holder.

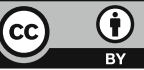

